\title{
Eivind Kolflaath
}

Bevisbedømmelse i praksis

\section{Fagbokforlaget, Bergen 2013 (269 sider)}

Innan Eivind Kolflaath kom ut med den här aktuella boken har han hunnit publicera flera bevisteoretiska och bevisrättsliga artiklar. Här kan bl.a. nämnas »Bevisbedømmelse - sannsynlighet eller fortellningar« (Jussens venner 2004, s. 279304), »Bevisbedømmelse som slutning til beste forklaring « (TfR 2007, s. 171219) och »Bevist utover enhver rimelig tvil« (TfR 2011 s. 135-196). I dessa artiklar visar sig Kolflaath vara en eminent kännare av både nordisk och internationell bevisteori. Texterna ger också vid handen att Kolflaath inte bara behärskar den kunskapsteoretiska diskussionen utan han har även satt sig in i de processuella regler som styr bevisningen i den konkreta rättegången.

Kolflaaths bevisteoretiska forskning når ett slags höjdpunkt $\mathrm{i}$ »Bevisbedømmelse i praksis«. Det kan påpekas att boken handlar uteslutande om straffmål. Universitet i Bergen, där Kolflaath fungerar som professor, har även fått fram högklassisk civilprocessuell forskning. Här kan särskilt nämnas Magne Strandbergs doktorsavhandling »Beviskrav i sivile saker« från 2012. Delar av Strandbergs avhandling finns publicerad på svenska av verket »Bevis 9《 (Christian Diesen - Magne Strandberg: Bevisprövning i tvistemål. Teori och praktik) från 2012.

Kolflaath förklarar i bokens inledande kapitel bl.a. skillnaden mellan rättstilllämpning och bevisvärdering. Den senare verksamheten har enligt honom fått rätt liten uppmärksamhet i den juridiska litteraturen. Delvis beror detta på att man inom juristkåren allmänt tror att bevisvärderingen kan skötas med sunt förnuft. Samtidigt har den existerande juridiska forskningens iver för matematik och sannolikhetskalkyler gjort vanliga jurister skeptiska till nyttan av bevisteoretiska undersökningar. Kolflaath vill själv inte godta en bevisteori grundad på sannolikhetsmodeller. Men samtidigt är han inte heller beredd att tillskriva intuitionen och helhetsbedömningar en oinskränkt makt. Den av honom presenterade rationella bevisprövningsmodellen grundas på principer som bidrar till att hitta den materiella sanningen i målet (s. 21). Inledningskapitlet ger också vid handen att Kolflaath kommer att använda sin bevismodell på ett omfattande empiriskt material hämtat från konkreta rättssaker som behandlats vid de norska lagmansrätterna.

Kapitel 2 handlar om den konkreta bevisbedömningen som forskningsobjekt. Kolflaath går här igenom den empiriska forskningens möjligheter på detta område. Han skiljer mellan öppet deltagande och hemligt deltagande. Men man kan också bara göra observationer utan att delta i själva verksamheten. Utöver detta är 
det möjligt att använda frågeformulär och djupintervjuer. Kolflaath själv betonar att den typ av observationsforskning han bedriver kräver tillräcklig juridisk kunskap. Det faktum att Kolflaath själv inte är jurist har krävt en betydande inlärningsinsats från hans sida.

I kapitel 3 redogör Kolflaath för hur han samlat in det empiriska material som ingår i boken. Vi får reda på att han har medverkat som observatör i sammanlagt 105 brottmål i lagmansrätten. Eftersom de allvarligaste brottmålen behandlas i jury i tingsrätten och har en likadan sammansättning i lagmansrätten valde Kolflaath att rikta sig in på lindrigare mål som behandlas av juristdomare och meddomare. Sistnämnda är inte juristdomare och motsvaras i Sverige och Finland av begreppet nämndemän. De mål, vars behandling Kolflaath följde med i lagmansrätten, har måst genomgå sållning till lagmansrätten, vilket betyder att de inte är av bagatellnatur.

Kolflaath har i nämnda 105 mål suttit med i domsöverläggningen. Hans slutsatser om den faktiska bevisprövningen i ett konkret mål grundar sig på läsning av de rättsliga texterna (underrättsdomen, besvärsskrifterna och domen i lagmansrätten) samt de skriftliga anteckningar han gjorde under domsöverläggningen. Hans tystnadsplikt gjorde att resultaten från domsöverläggningarna helt har anonymiserats. I sina tidigare bevisteoretiska artiklar har Kolflaath gått igenom olika aspekter på bevisbedömningen. I den nu aktuella boken vill Kolflaath skapa en helhetsbild av dessa aspekter, närmast hur de kan anpassas till varandra. Kolflaath vill också ta ställning till om dessa aspekter (eller metoder) hittas i det empiriska materialet. Han gör även en utvärdering av metodernas förmåga att komma sanningen på spåret.

Kapitel 4 bär rubriken »Slutledninger från bevis« och kan sägas innehålla Kolflaaths syn på den grundläggande bevisrättsliga terminologin. Han skiljer mellan bevisdata, bevisfakta och rättsfakta. Jag uppfattar bevisdata som bevismedel, dvs. något mer eller mindre objektivt, som vittnen och sakkunniga. Dessa kan uttala sig direkt om rättsfakta som när en polis vittnar om att gärningsmannen inte stannade för stopptecknet. Men det kan också finnas mellanliggande bevisfakta om leder till slutsatsen. Bevisrelationen mellan bevisfakta och rättsfakta stärks med s.k. relevansargument. Det är närmast frågan om i vilken grad bevisfaktum är ägnat att påverka sannolikheten för rättsfaktum. Det kan observeras att Kolflaath här inte för någon egentlig diskussion med bevisteoretiker från övriga Norden. Denna diskussion har han fört i sina bevisartiklar.

I kapitel 5, som bär rubriken »Hethetlige fortellinger«, försöker Kolflaath förklara varför slutledningsperspektivet inte räcker till. Bl.a. griper olika fakta in i varandra. Men åtalet som en hypotes om det inträffade påverkar också domarens 
syn på bevisdata. Bevisen finns helt enkelt i ett visst sammanhang. Slutledningsanalysen kan inte greppa detta helt eftersom den bygger på en riktning, från data till rättsfakta. Men hur värdera bevisvärdet av den samlade bevismängden? Här behövs ett annat perspektiv och enligt Kolflaath har här berättelseperspektivet mycket att ge (s. 96).

Kapitel 6 handlar om »fortellingens plausibiltet«. Med detta begrepp vill Kolflath visa på berättelsens harmoni med faktiska händelser i målet. Han talar också om koherens. Det finns en generell plausibilitet som innebär att berättelsen sitter ihop, alltså ingen disharmoni. Han går sedan igenom fall som kännetecknas av spänningar och brister. Rätt långt handlar det om promillekörning. Kolflaath tar också upp det han kallar sakspecifik plausibilitet. Här beaktas fakta i målet mera konkret. Enligt Kolflaath utgör berättelseperspektivet ett nödvändigt supplement till slutningsperspektivet. Helt allmänt får det inte finnas en plausibel frikännande förklaring.

I kapitel 7 behandlar författaren sökandet efter förklaringar. Enligt honom förenar förklaringsperspektivet slutlednings- och berättelsemodellerna. Det kanske mest centrala är preciseringen av hur testandet av hypoteser om den tilltalades oskyldighet bäst skall göras. Han formulerar testet eller beviskravet enligt följande:

(1) Anta at tiltalte er uskyldig etter tiltalen. Undersøk om det finnes bevis og andre etablerte omstendigheter som - hver for seg eller i kombinasjon - i så fall blir vanskelige å forklare.

(2) Anta at tiltalte er skyldig etter tiltalen. Undersøk om det finnes etablerte omstendigheter som (hver for seg eller i kombinasjon) i så fall blir vanskelige å forklare (s. 209).

I boken belyses denna tankemodell med hjälp av konkreta exempel hämtade från det empiriska materialet.

Kapitel 8 avslutar arbetet. Detta kapitel är inte bevisteoretiskt utan närmast rättssociologiskt. Här presenterar Kolflaath ett slags rapport om vad som hände under överläggningarna till dom. Likaså får vi en beskrivning av hur domstolen kommer fram till avgörandet i sak.

Kolflaaths bok utgör en alltigenom imponerande rättsvetenskaplig prestation. Enligt vad jag känner till är han den första i Norden som på detta sätt lyckats förena djupa och självständiga bevisteoretiska insikter med ett mycket omfattande empiriskt material. Införskaffandet av det i boken använda empiriska materialet har därtill krävt en arbetsinsats som går långt utanför det vanliga inom rättsveten- 
skapen. Det unika empiriska materialet har gett Kolflaath möjlighet att belysa sin bevismodell med exempel som känns verkliga och inte konstruerade. Att mycket kretsar kring promillekörning och andra typer av trafikbrott är ingen nackdel, snarare tvärtom. I verkliga livet skapar just denna typ av mål ofta svåra bevisproblem.

Dan Frände 